\title{
Wider Still and Wider: Corporate Constitutionalism Unbounded
}

\section{Citation}

Armitage, David. 2015. "Wider Still and Wider: Corporate Constitutionalism Unbounded."

Itinerario 39 (03) (December): 501-503. doi:10.1017/s0165115315000911.

\section{Published Version}

doi:10.1017/S0165115315000911

\section{Permanent link}

http://nrs.harvard.edu/urn-3:HUL.InstRepos:27715960

\section{Terms of Use}

This article was downloaded from Harvard University's DASH repository, and is made available under the terms and conditions applicable to Open Access Policy Articles, as set forth at http:// nrs.harvard.edu/urn-3:HUL.InstRepos:dash.current.terms-of-use\#OAP

\section{Share Your Story}

The Harvard community has made this article openly available.

Please share how this access benefits you. Submit a story.

Accessibility 


\title{
Wider Still and Wider: \\ Corporate Constitutionalism Unbounded
}

\author{
DAVID ARMITAGE
}

Will Pettigrew's article, "Corporate Constitutionalism and the Dialogue between the Global and the Local in Seventeenth Century English History," presents an excitingly expansive research agenda that cuts across many of the traditional divisions of early modern history: domestic and foreign, internal and imperial, constitutional and commercial, English and British, British and European, national and global. The scope of this programme is as breathtaking as it is thoughtprovoking. It might therefore seem perverse to ask for something still more ambitious, as I shall do in these brief remarks. However, in gesturing towards an even greater vision of what Pettigrew calls "corporate constitutionalism," my hope is to clarify rather than to complicate the immense task he has set himself and his collaborators on the "Political Economies of International Commerce" project.1

That project is only the most visible and prominent current manifestation of what Pettigrew calls the "constitutional turn" in the history of corporations. Three motives behind that turn stand out. First, there is the presentist anxiety over corporate power, even corporate corruption, on a worldwide scale since the global financial crisis of $2008 .^{2}$ Second, there is the more exactingly historical movement to recover the multiple similarities, particularly in the early modern period, between trading corporations and sovereign states, or what are now coming to be called "company-states". ${ }^{3}$ And third there is the still more fundamental, but as yet less well

1 University of Kent, "Political Economies of International Commerce": http://peic.org.uk/.

2 Joshua Barkan, Corporate Sovereignty: Law and Government under Capitalism (Minneapolis: University of Minnesota Press, 2013), is a sophisticated treatment explicitly tied to recent events.

${ }^{3}$ Philip J. Stern, The Company-State: Corporate Sovereignty and the Early Modern Foundations of the British Empire in India (Oxford: Oxford University Press, 2011); Arthur Weststeijn, "The VOC as a Company-State: Debating Seventeenth-Century Dutch Colonial Expansion," Itinerario 38 (2014): 13-34. 
developed, understanding that companies and states were divergent species within the genus of corporations, in the Roman-law sense of collective bodies represented as persons for the purpose of fulfilling duties and bearing rights. ${ }^{4}$ Taken together, these three impulses-reaching back respectively over the courte, moyenne and longue durées-suggest that the only mystery about the constitutional turn is not why it is happening at all, but why it has taken so long to gather speed.

One reason for the hesitancy may be the default assumption, particularly among modern historians, that "corporation" means primarily or even exclusively a commercial body. This is perhaps a mistake few people brought up in English boroughs or towns-those municipal "corporations" that supply public services such as water, swimming-baths and street-cleaning-might make. Nonetheless, it remains widespread. Pettigrew is not entirely innocent of it, as the opening lines of his article invoke present discontents about "corporations" in this specifically financial sense. Such a truncated definition of the corporation is clearly anachronistic for the period Pettigrew focuses on even if he, along with many other present-minded commentators, implicitly views the seventeenth century as the long birth moment of the modern corporation. ${ }^{5}$

A slightly longer perspective might question that chronology. As Pettigrew notes, even among the subset of English overseas commercial corporations he studies were sixteenth-century foundations, pre-eminently the Muscovy Company. ${ }^{6}$ Moreover, for all their pretensions to perpetuity, few of the early modern English commercial companies staggered into the modern age, the latter-day revival of the East India Company as a high-end gift-shop notwithstanding. ${ }^{7}$ What Pettigrew terms

\footnotetext{
4 F. W. Maitland, State, Trust and Corporation, eds. David Runciman and Magnus Ryan (Cambridge: Cambridge University Press, 2003).

${ }^{5}$ Nick Robins, The Corporation that Changed the World: How the East India Company Shaped the Modern Multinational, $2^{\text {nd }}$ edition (London: Pluto, 2012); William Dalrymple, The Anarchy: How a Corporation Replaced the Mughal Empire, 1756-1803 (London: Bloomsbury, 2016).

6 Thomas Stuart Willan, The Early History of the Russia Company, 1553-1603 (Manchester: Manchester University Press, 1956). A new history of the Muscovy Company is a major desideratum.

7 The East India Company Fine Foods: http://www.eicfinefoods.com/.
} 
"corporate longevity" might actually appear to be rather shortlived sub specie aeternitatis.

The vision of the corporation and its relation to constitutionalism could be even more expansive in time. Even in purely English context, this would entail a very "long" seventeenth century going back at least to 1553 (and the foundation of the Muscovy Company) and forward well into the nineteenth-century afterlives of the East India Company and the Hudson's Bay Company, for instance, or to the recrudescence of private companies such as the British South Africa Company, and the Royal Niger Company in the "scramble" for Africa and beyond. It might also demand unpicking the alleged elective affinity between corporations and capitalism by unpacking the multiple early modern links between commercial corporations and other forms of corporation: for example, states, chartered towns and the London livery companies, some of which (like the Clothworkers' Company), through their promotion of long-distance trade, had an extra-European impact even before the dawn of the seventeenth century. ${ }^{8}$

These various links also need to be put into the context of the longer history of corporations going back to Roman law: in this regard, recent studies of Thomas Hobbes's conceptions of corporations (and his connections to the Virginia Company) provide models for articulating the history of early modern political thought with the history of corporate personhood in all its myriad forms. ${ }^{9}$ To focus only on trading corporations assumes what needs to be explained: that is, why only some of the proliferation of corporations in early modern England turned outward, beyond the realm, as commercial organisations. Other legally constituted agents could operate in the extra-European world: naval captains, army officers, clerics and

\footnotetext{
8 G. D. Ramsey, "Clothworkers, Merchant Adventurers, and Richard Hakluyt," English Historical Review 92 (1977): 504-21; on the London companies, 1400-1900, see "Records of London's Livery Companies Online": http://www.londonroll.org/home. 9 Noel Malcolm, "Hobbes, Sandys, and the Virginia Company," in Malcolm, Aspects of Hobbes (Oxford: Oxford University Press, 2002), pp. 53-79; Mathias Hein Jessen, "The State of the Company: Corporations, Colonies and Companies in Leviathan," Journal of Intellectual History and Political Thought 1 (2012): 56-85; Patricia Springborg, "Hobbes, Donne and the Virginia Company: Terra Nullius and "The Bulimia of Dominion'," History of Political Thought 36 (2015): 113-64.
} 
consuls, for instance. ${ }^{10}$ Why, then, did the English crown increasingly multiply and sub-contract the marks of sovereignty-among them treaty-making, the powers of war and peace, adjudication, territorial claim-making and the minting of coinageto such corporations in the wider world within and beyond Europe? And what effect might that selection process have had on the constitution of sovereignty within Britain itself?

There have been intermittent answers to such questions over the years-for example, regarding the politics of the Virginia Company, the Providence Island Company or the founding of Pennsylvania ${ }^{11}$-but we still lack a convincingly comprehensive narrative of developments across the seventeenth century. Constructing that story might also demand a robust counterfactual from beyond England or Britain. Fortunately, there are factual counterfactuals to hand, in the histories of other early modern European countries that deployed commercial companies overseas. These included not just those Pettigrew lists-"Spain, Portugal, Holland, France, Denmark, and Sweden"-but also Brandenburg and Scotland as well. Such comparisons could reveal what, if anything, was peculiar about the English case, in the long seventeenth century or beyond. The Netherlands provides the most obvious parallel in the VOC, but the burgeoning scholarship on French commercial companies, notably the eighteenth-century Compagnie des Indes, should clarify whether England was part of pan-European developments articulated on a global scale. ${ }^{12}$ This suggestion might place greater demands on Pettigrew's project than it can immediately bear. However, it does affirm the logic of one of his

${ }^{10}$ On consular jurisdiction, see especially Tristan M. Stein, "The Mediterranean and the English Empire of Trade, 1660-1748" (Ph.D. dissertation, Harvard University, 2012).

${ }^{11}$ Karen Ordahl Kupperman, Providence Island, 1630-1641: The Other Puritan Colony (Cambridge: Cambridge University Press, 1993); David Armitage, "Greater Britain: A Useful Category of Historical Analysis?," American Historical Review 104 (1999): 441 and n. 72.

${ }^{12}$ Felicia Gottmann, "French-Asian Connections: The Compagnie des Indes, France's Eastern Trade, and New Directions in Historical Scholarship," The Historical Journal 56 (2013): 537-52; Elizabeth Cross, "The Compagnie des Indes and the Fate of Commercial Empire in the French Revolution" (Ph.D. dissertation, Harvard University, in progress). 
own questions-"How could a constitutional approach to Dutch, French, Spanish, and Portuguese trading corporations integrate European examples?"- by seeking to integrate English corporate constitutionalism into a firmly pan-European framework, much as Jack P. Greene twenty-five years ago traced constitutionalism in an imperial and trans-Atlantic context or Linda Colley has more recently done for anglophone constitution-making in global perspective. ${ }^{13}$

The contemporary stakes of Pettigrew's larger project are clear. Its place on the leading edge of current historiography is also evident. Its relation to the longer, more variegated history of legal corporatism is for the moment less obvious. After all, it was only in the nineteenth century, starting in the Anglo-American world, that the meaning of the term "corporation" narrowed to mean mostly an incorporated business entity. ${ }^{14}$ It made sense to distinguish commercial bodies from other species of corporation only when the spheres of politics and the economy had separated, a process that had barely begun in the seventeenth century. ${ }^{15}$ Before that separation, the term "corporate constitutionalism" might even seem to be a pleonasm, covering corporations aggregate and corporations sole, from the Crown to chartered towns and companies and a great deal between. Whether corporate constitutionalism is a useful category of historical analysis remains to be seen: a generous focus-broad in space, deep in time-will be essential to assess its utility. In the words of one of Britain's unofficial anthems, which aptly places a vision of freedom in a global sphere of action, "wider still and wider" should its "bounds be set."

${ }^{13}$ Jack P. Greene, Peripheries and Center: Constitutional Development in the Extended Polities of the British Empire and the United States, 1607-1788 (New York: W. W. Norton, 1990); Linda Colley, "Empires of Writing: Britain, America and Constitutions, 1776-1848," Law and History Review 32 (2014): 237-66.

${ }^{14}$ Oscar Handlin and Mary F. Handlin, "Origins of the American Business Corporation," Journal of Economic History 5 (1945): 1-23; Jason Kaufman, "Corporate Law and the Sovereignty of States," American Sociological Review 73 (2008): 402-25.

${ }^{15}$ Istvan Hont, Jealousy of Trade: International Competition and the Nation-state in Historical Perspective (Cambridge, Mass.: The Belknap Press of Harvard University Press, 2005); David Singh Grewal, The Invention of the Economy: The Origins of Economic Thought (Cambridge, Mass.: Harvard University Press, forthcoming). 